Gut, 1967, 8, 332

\title{
Prognosis after resection of chronic regional ileitis
}

\author{
J. E. LENNARD-JONES ${ }^{1}$ AND GEORGE A. STALDER ${ }^{2}$ \\ From the Central Middlesex and St. Mark's Hospitals, London, England
}

EDITORIAL COMMENT This follow-up study excludes any diagnostic uncertainty as it concerns only patients with chronic regional ileitis who needed surgical treatment. It therefore enables clear-cut, valuable data to be presented on the recurrence rate and mortality of Crohn's disease.

Recurrence of the disease after resection of the diseased bowel is a well-recognized complication in the surgical treatment of regional ileitis. Published estimates of the recurrence rate, however, vary widely. Part of this variability is due to different lengths of follow-up, and part to the use of different definitions of recurrence and different methods of statistical analysis. These factors prevent valid comparisons between recurrence rates in different types of disease or with different types of treatment.

In this paper, we put forward three possible definitions of recurrence and show in a series of cases that, as expected, the recurrence rate decreases as more stringent definitions are used. We have analysed the data by a standard actuarial method which makes the greatest possible use of the available information and enables the probability of recurrence in a given time after operation to be estimated.

Using these definitions and this method of analysis in a prospective survey it should be possible to obtain comparisons between the results of a single treatment in different types of disease and between the results of different treatments in a homogeneous series of cases.

\section{METHOD OF STUDY}

SELECTION OF PATIENTS All 78 patients in whom a first or second resection for chronic regional ileitis has been performed at the Central Middlesex Hospital (42 patients) from 1949 to 1964 and at St. Mark's Hospital (36 patients) from 1947 to 1964 have been analysed. Other types of operation on patients with regional ileitis have not been included; only five patients had a third or fourth resection and this group is too small for analysis.

The diagnosis has been made on the clinical and radiological features, combined with the appearance at laparotomy and the pathological features of the resected specimen. In some cases the histological findings were

${ }^{1}$ Member, Medical Research Council Gastroenterology Research Unit.

'In receipt of a fellowship from the Stiftung für Medinisch-Biologische Stipendien, Zurich, Switzerland. non-specific but the macroscopic appearance of the specimen and the clinical course of the disease left little doubt as to the diagnosis. In every patient the disease affected mainly the terminal ileum; 30 patients in whom the adjacent colon was also affected were accepted for the study. In three patients there was a 'skip' lesion higher up the ileum which was also resected and in four patients the sigmoid colon was involved by serosal adhesion.

METHOD OF FOLLOW-UP Follow-up commenced from the date of operation and ended in 1964 or 1965 . Fifty-one patients were followed at hospital and 27 patients were followed by letter either to the local doctor (14) or the patient (13). Follow-up is complete in 73 of the 78 patients, three of the five lost to follow-up having left the country.

STATISTICAL ANALYSIS The results have been analysed by constructing life (or recurrence) tables (Bradford Hill, 1966). In each table, an example of which is shown in Table I, the years after treatment are set out with the number alive (or free of recurrence) at the beginning of the year, the number who were followed for only part of that year, and the number dying (or suffering a recurrence) during the year. By convention, those followed for only part of the year are regarded as having been followed for half a year, since some will have been followed for more and some less than six months. The proportion of patients dying (or suffering a recurrence) and the proportion surviving (or suffering no recurrence) during each year can now be calculated. The probability of surviving (or suffering no recurrence) from the time of operation to the end of any given year is obtained from the product of proportions surviving in intervening years.

DEFINITIONS A recurrence of the disease has been defined in three ways:

Symptomatic recurrence (group 1) Some symptoms, particularly diarrhoea, are common after resection of the terminal ileum. An increase in these symptoms, usually associated with pain and weight loss, has been regarded as a symptomatic relapse. This return of symptoms does not necessarily indicate recurrence of the disease and will tend to overestimate the relapse rate. For example, the symptoms might be due to adhesions or to simple stric- 
ture at the anastomosis. The recurrence of an anal lesion alone without evidence of recurrent Crohn's disease elsewhere in the gut has not been regarded for the purpose of this analysis as a recurrence of disease.

Symptomatic relapse with radiological and/or surgical evidence of recurrent disease (group 2) Patients in group 1, who developed further symptoms, as described above, and in whom there was radiological and/or surgical evidence of recurrent disease are included in this category. In some of these cases recurrence of the disease affected mainly the colon.

Further resection for Crohn's disease Patients in groups 1 and 2 whose recurrent symptoms necessitated further resection of the gut and in whom pathological examination of the resected specimen showed evidence of Crohn's disease.

\section{RESULTS}

FIRST RESECTION Seventy-three patients had a first resection for regional ileitis; nine of these patients had had a previous unsuccessful diversion operation. In 62 patients, the operation performed was a right hemicolectomy, in four patients a segment of ileum was resected with end-to-end anastomosis, and in seven patients a right hemicolectomy was performed plus resection of a small segment of ileum or colon involved either as a 'skip' lesion or by contact with the diseased terminal ileum. Two patients died in the post-operative period and are not considered in calculations of the recurrence rate.

Symptomatic recurrence Twenty-seven of the 71 survivors from the operation had symptoms suggesting a recurrence of the disease. The periods of follow-up and the relapses in each year after operation are shown in Table I. The calculated probability among survivors from the operation of symptomatic recurrence within five years was 0.31 and within 10 years was $0 \cdot 58$.

TABLE 1

PATIENTS DEVELOPING A RECURRENCE OF SYMPTOMS IN EACH OF THE FIRST 10 YEARS AFTER A FIRST RESECTION FOR REGIONAL ILEITIS

\begin{tabular}{|c|c|c|c|c|c|c|c|c|c|}
\hline \multirow{2}{*}{$\begin{array}{l}\text { Year } \\
\text { after } \\
\text { Operation }\end{array}$} & \multirow{2}{*}{$\begin{array}{l}\text { Well at } \\
\text { Beginning } \\
\text { of Year }\end{array}$} & \multirow{2}{*}{$\begin{array}{l}\text { Lost to } \\
\text { Follow-up } \\
\text { during Year } 1\end{array}$} & \multirow{2}{*}{$\begin{array}{l}\text { Well } \\
\text { (observed } \\
\text { only part of } \\
\text { year) }\end{array}$} & \multicolumn{4}{|c|}{ During Each Year } & \multicolumn{2}{|c|}{ Since First Resection } \\
\hline & & & & $\begin{array}{l}\text { Exposed to } \\
\text { Risk of } \\
\text { Relapse }\end{array}$ & $\begin{array}{l}\text { Number of } \\
\text { Relapses }\end{array}$ & $\begin{array}{l}\text { Proportion } \\
\text { with } \\
\text { Relapse }\end{array}$ & $\begin{array}{l}\text { Proportion } \\
\text { without } \\
\text { Relapse }\end{array}$ & $\begin{array}{l}\text { Estimated } \\
\text { Proportion } \\
\text { without } \\
\text { Relapse to } \\
\text { End of Each } \\
\text { Year }\end{array}$ & $\begin{array}{l}\text { Estimated } \\
\text { Proportion } \\
\text { with } \\
\text { Relapse to } \\
\text { End of Each } \\
\text { Year }\end{array}$ \\
\hline $\begin{array}{l}0- \\
1- \\
2- \\
3- \\
4- \\
5- \\
6- \\
7- \\
8- \\
9-\end{array}$ & $\begin{array}{r}71 \\
60 \\
50 \\
39 \\
38 \\
31 \\
21 \\
14 \\
11 \\
9\end{array}$ & $\begin{array}{l}2 \\
2\end{array}$ & $\begin{array}{l}3 \\
2 \\
6 \\
1 \\
4 \\
7 \\
5 \\
1 \\
1 \\
2\end{array}$ & $\begin{array}{l}68 \cdot 5 \\
58 \\
47 \\
38 \cdot 5 \\
35 \cdot 5 \\
27 \cdot 5 \\
18 \cdot 5 \\
13 \cdot 5 \\
10 \cdot 5 \\
8 \cdot 0\end{array}$ & $\begin{array}{l}6 \\
6 \\
5 \\
0 \\
2 \\
3 \\
2 \\
2 \\
1 \\
0\end{array}$ & $\begin{array}{l}0.0876 \\
0 \cdot 1034 \\
0 \cdot 1064 \\
0.0000 \\
0.0563 \\
0.1091 \\
0.1081 \\
0 \cdot 1481 \\
0.0952 \\
0.0000\end{array}$ & $\begin{array}{l}0.9124 \\
0.8966 \\
0.8936 \\
1.0000 \\
0.9437 \\
0.8909 \\
0.8919 \\
0.8519 \\
0.9048 \\
1.0000\end{array}$ & $\begin{array}{l}0.9124 \\
0.8181 \\
0.7311 \\
0.7311 \\
0.6899 \\
0.6146 \\
0.5482 \\
0.4670 \\
0.4225 \\
0.4225\end{array}$ & $\begin{array}{l}0.0876 \\
0 \cdot 1819 \\
0.2689 \\
0.2689 \\
0.3101 \\
0.3854 \\
0.4518 \\
0 \cdot 5330 \\
0.5775 \\
0.5775\end{array}$ \\
\hline
\end{tabular}

${ }^{1}$ By convention each of these patients contributes half a year.

TABLE II

PATIENTS DEVELOPING A RECURRENCE OF SYMPTOMS PLUS RADIOLOGICAL AND/OR SURGICAL EVIDENCE OF RECURRENT DISEASE IN EACH OF THE FIRST 10 YEARS AFTER A FIRST RESECTION FOR REGIONAL ILEITIS

$\begin{array}{llllll}\text { Year } & \text { No Evidence } & \text { Lost to } & \text { No Evidence of } & \text { Number with } \\ \text { after } & \text { of Recurrence } & \text { Follow-up } & \text { Recurrence } & \text { Evidence of } \\ \text { Operation } & \text { at Start of Year } & \text { during Year } 1 & \text { (observed only } & \text { Recurrence } \\ & & & \text { part of year) }\end{array}$

\begin{tabular}{|c|c|c|c|c|c|}
\hline $\begin{array}{l}0- \\
1- \\
2- \\
3- \\
4- \\
5- \\
6- \\
7- \\
8- \\
9-\end{array}$ & $\begin{array}{r}71 \\
62 \\
55 \\
41 \\
39 \\
32 \\
21 \\
15 \\
11 \\
9\end{array}$ & $\begin{array}{l}2 \\
2 \\
1\end{array}$ & $\begin{array}{l}5 \\
3 \\
6 \\
2 \\
5 \\
9 \\
5 \\
1 \\
1 \\
2\end{array}$ & $\begin{array}{l}2 \\
2 \\
8 \\
0 \\
1 \\
2 \\
1 \\
3 \\
1 \\
0\end{array}$ & $\begin{array}{l}0.0296 \\
0.0622 \\
0.2064 \\
0.2064 \\
0.2285 \\
0.2846 \\
0.3233 \\
0.4633 \\
0.5144 \\
0.5144\end{array}$ \\
\hline
\end{tabular}

1 By convention each of these patients contributes half a year. 
Symptomatic relapse with radiological and/or surgical evidence of recurrent disease Twenty patients had further symptoms with radiological and/or surgical evidence of recurrent disease. The periods of follow-up and the numbers of patients developing recurrent disease in each year after the operation are shown in Table II. The calculated probability of recurrence within five years was 0.23 and within 10 years was 0.51 .

Further resection for Crohn's disease Twelve patients had a further resection for recurrence of the disease (Table III); the calculated probability of a second resection being required within five years was $0 \cdot 16$ and within 10 years was $0 \cdot 26$. In 11 patients the recurrence involved the ileum at the anastomosis and in one patient the colon and rectum as well.

Mortality Six patients died during the follow-up period; five deaths can be attributed to Crohn's disease (Tables IV and V). The calculated probability of death from Crohn's disease within five years of the first resection was 0.07 and within 10 years was $0 \cdot 12$.
TABLE V

\section{CAUSES OF DEATH IN THIS SERIES}

$\begin{array}{llllll}\text { Surgical complication after first resection } & \text {. } & \text {. } & \text {.. } & 2\end{array}$

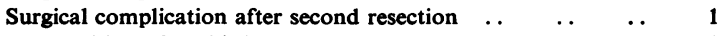
Malnutrition after third resection $\quad$.

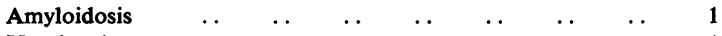

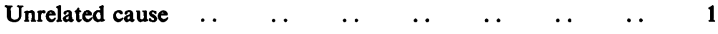

RESULTS IN DIFFERENT GROUPS OF PATIENTS AFTER FIRST RESECTION It has been suggested that, among other factors, the prognosis after resection for Crohn's disease depends on the age of the patient and the length of history. The results have therefore been analysed to show results in different age groups, patients with different length of history, and in men and women. Data were insufficient to analyse other factors suggested as influencing prognosis.

Effect of age The mean age of the surviving patients at the time of operation was 35.3 years with a range of 16 to 23 years. Thirty-seven patients were aged less than 35 years and 34 were aged 35 years or more. The calculated probability of recurrence with

TABLE I II

PATIENTS HAVING A SECOND RESECTION FOR RECURRENT CROHN'S DISEASE IN EACH OF THE FIRST 10 YEARS AFTER A FIRST RESECTION FOR REGIONAL ILEITIS

\begin{tabular}{|c|c|c|c|c|c|}
\hline $\begin{array}{l}\text { Year } \\
\text { after } \\
\text { Operation }\end{array}$ & $\begin{array}{l}\text { No Second } \\
\text { Resection at } \\
\text { Start of Year }\end{array}$ & $\begin{array}{l}\text { Lost to } \\
\text { Follow-up } \\
\text { during Year }{ }^{1}\end{array}$ & $\begin{array}{l}\text { No Second } \\
\text { Resection }{ }^{1} \\
\text { (observed only } \\
\text { part of year) }\end{array}$ & $\begin{array}{l}\text { Number with } \\
\text { Second } \\
\text { Resection }\end{array}$ & $\begin{array}{l}\text { Estimated Proportion } \\
\text { Having Second Resection } \\
\text { to End of Each Year }\end{array}$ \\
\hline $\begin{array}{l}0- \\
1- \\
2- \\
3- \\
4- \\
5- \\
6- \\
7- \\
8- \\
9-\end{array}$ & $\begin{array}{l}71 \\
62 \\
56 \\
47 \\
43 \\
36 \\
26 \\
20 \\
15 \\
14\end{array}$ & $\begin{array}{l}2 \\
2\end{array}$ & $\begin{array}{l}5 \\
3 \\
6 \\
2 \\
5 \\
8 \\
6 \\
4 \\
1 \\
2\end{array}$ & $\begin{array}{l}2 \\
1 \\
3 \\
2 \\
1 \\
2 \\
0 \\
1 \\
0 \\
0\end{array}$ & $\begin{array}{l}0.0296 \\
0.0459 \\
0.0999 \\
0.1391 \\
0.1606 \\
0.2131 \\
0.2131 \\
0.2569 \\
0.2569 \\
0.2569\end{array}$ \\
\hline
\end{tabular}

${ }^{1}$ By convention each of these patients contributes half a year.

TABLE IV

PATIENTS DYING OF CROHN'S DISEASE IN EACH OF THE FIRST 10 YEARS AFTER A FIRST RESECTION FOR REGIONAL ILEITIS

\begin{tabular}{|c|c|c|c|c|c|c|}
\hline $\begin{array}{l}\text { Year } \\
\text { after } \\
\text { Operation }\end{array}$ & $\begin{array}{l}\text { Alive } \\
\text { at Start } \\
\text { of Year }\end{array}$ & $\begin{array}{l}\text { Lost to } \\
\text { Follow-up } \\
\text { during Year } 1\end{array}$ & $\begin{array}{l}\text { Died of } \\
\text { Other Cause } \\
\text { during Year }\end{array}$ & $\begin{array}{l}\text { Alive } \\
\text { (observed only } \\
\text { part of year) }\end{array}$ & $\begin{array}{l}\text { Death from } \\
\text { Crohn's Disease } \\
\text { during Year }\end{array}$ & $\begin{array}{l}\text { Estimated Proportion } \\
\text { Dying of Crohn's } \\
\text { Disease to End of } \\
\text { Each Year }\end{array}$ \\
\hline $\begin{array}{l}0- \\
1- \\
2- \\
3- \\
4- \\
5- \\
6- \\
7- \\
8- \\
9-\end{array}$ & $\begin{array}{l}73 \\
64 \\
59 \\
53 \\
50 \\
40 \\
31 \\
25 \\
20 \\
18\end{array}$ & $\begin{array}{l}2 \\
2\end{array}$ & $1^{2}$ & $\begin{array}{l}5 \\
3 \\
6 \\
3 \\
7 \\
9 \\
5 \\
5 \\
1 \\
3\end{array}$ & 2 & $\begin{array}{l}0.0288 \\
0.0288 \\
0.0288 \\
0.0288 \\
0.0710 \\
0.0710 \\
0.0710 \\
0.0710 \\
0.1187 \\
0.1187\end{array}$ \\
\hline
\end{tabular}

${ }^{1} B y$ convention each of these patients contributes half a year.

'Died carcinoma of rectum. 
radiological and/or surgical evidence of recurrent disease for both age groups within five years was $\mathbf{0} 23$.

Effect of sex Forty-two of the patients were men and 29 were women. The calculated probability of recurrence within five years was 0.21 for men and 0.26 for women.

Effect of length of history One patient presented as a surgical emergency without previous history, 14 patients had a history of less than one year before operation, 30 patients had a history of up to two years, and 41 a history of over two years. The longest history of symptoms before operation was 31 years, and the mean length of history was five years. The calculated probability of recurrence within five years in those with a history of two years or less was 0.24 as compared with 0.21 in those with a longer history.

SECOND RESECTION Sixteen patients had a second resection for a recurrence of Crohn's disease involving the ileum at the anastomosis. Five of these patients had the first resection elsewhere and are therefore not included in the previous results. One patient died in the post-operative period and is not included in calculations of the relapse rate. The results have been analysed up to five years.

Symptomatic recurrence Ten of the 15 survivors from the second operation had symptoms suggesting a recurrence of disease. The calculated probability of symptomatic recurrence within the first five years was $\mathbf{0 \cdot 8 0}$.

Symptomatic recurrence with radiological and/or surgical evidence of recurrent disease Eight patients suffered such a recurrence, the calculated probability during the first five years (Table VI) being 0.67.

Further resection for Crohn's disease Six of the 15 patients have had a third resection for recurrent disease, the calculated probability of requiring a third resection during the first five years being 0.57 .

\section{TABLE VI}

PATIENTS WITH RECURRENT SYMPTOMS PLUS RADIOLOGICAL AND/OR SURGICAL EVIDENCE OF RECURRENT DISEASE IN EACH OF THE FIRST FIVE YEARS AFTER A SECOND RESECTION FOR REGIONAL ILEITIS

\begin{tabular}{lcccc}
$\begin{array}{l}\text { Year after } \\
\text { Second } \\
\text { Resection }\end{array}$ & $\begin{array}{l}\text { No Evidence } \\
\text { of } \\
\text { Recurrence } \\
\text { at Start } \\
\text { of Year }\end{array}$ & $\begin{array}{l}\text { No Evidence } \\
\text { of } \\
\text { Re currence } \\
\text { (observed } \\
\text { only part } \\
\text { of year) }\end{array}$ & $\begin{array}{l}\text { Evidence of } \\
\text { Recurrence } \\
\text { during Year }\end{array}$ & $\begin{array}{l}\text { Estimate } \\
\text { Proportio } \\
\text { with } \\
\text { Recurrence }\end{array}$ \\
\hline $0-$ & 15 & 2 & 3 & \\
$1-$ & 10 & & 3 & 0.2143 \\
$2-$ & 7 & 2 & 2 & 0.4500 \\
$3-$ & 5 & & 2 & 0.6700 \\
4 & 3 & & & 0.6700
\end{tabular}

${ }^{1}$ By convention each of these patients contributes half a year.
DISCUSSION

In this study we have tried to analyse a homogeneous series of patients. We have therefore limited the study to cases of chronic regional ileitis, excluding cases with Crohn's disease elsewhere in the gut, all treated by resection and all treated at the Central Middlesex and St. Mark's Hospitals. The actuarial method of analysis has been used to obtain the probability of recurrence of the disease or death from it after the operation.

A comparison between Tables I and III illustrates that a twofold difference in the calculated probability of recurrence may be obtained by using different definitions as to what constitutes evidence of recurrent disease. The analyses of the effect of age and length of previous history on the recurrence rate may have been affected by the decision to use 35 years of age and a history of two years as the dividing points between the two groups compared. These figures were chosen to divide the small total number into two approximately equal groups.

The estimated probabilities in this series show that after a first resection for regional ileitis, recurrent symptoms were likely in about one-third of the patients within five years and in a little over half within 10 years. Recurrent symptoms with radiological and/or surgical evidence of recurrent disease were likely in about one-quarter at five years and about one-half at 10 years. About one-sixth of the patients could be expected to require further resection within five years and one-quarter within 10 years. The estimated mortality rate from Crohn's disease after the first resection was $7 \%$ at five years and $12 \%$ at 10 years.

Follow-up data after a second resection for regional ileitis are limited to 15 patients and the small numbers allow few conclusions to be drawn from the analysis. In this small group the estimated probability of recurrence after a second resection was more than twice as great as after a first resection. If the recurrence rate is indeed greater it could be that these patients are particularly liable to recurrence or that extensive resection is avoided at the second operation.

It is difficult to compare the results in this series with those in other series because the selection of cases, the definitions of recurrence, and the methods of analysis differ so greatly in the various reports. Some recent figures on the observed recurrence rate after primary resection of regional ileitis are listed in Table VII.

The wide variation in the reported recurrence rates after a first resection will be seen. The need for a second resection, where this is specified, of $15.2 \%$, $20.6 \%$, and $26.5 \%$, corresponds well with the cal- 
TABLE VII

RECURRENCE RATES RECORDED IN THE LITERATURE

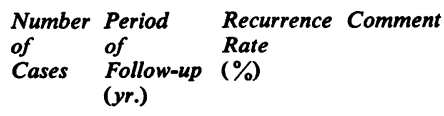

\begin{tabular}{|c|c|c|c|c|}
\hline $\begin{array}{l}\text { Van Patter, } \\
\text { Bargen, Dockerty, } \\
\text { Feldman, Mayo, } \\
\text { and Waugh (1954) }\end{array}$ & 230 & $>2$ & 62 & $\begin{array}{l}\text { 'Any reappearance } \\
\text { of the disease pro- } \\
\text { cess' }\end{array}$ \\
\hline $\begin{array}{l}\text { Crohn and Yarnis } \\
\text { (1958) }\end{array}$ & 62 & $1-25$ & $27 \cdot 4$ & \\
\hline Pollock (1958) & $\begin{array}{l}24 \\
11\end{array}$ & $\begin{array}{r}>5 \\
>10\end{array}$ & $\begin{array}{l}33 \\
45\end{array}$ & \\
\hline $\begin{array}{l}\text { Brown and } \\
\text { Daffner (1958) }\end{array}$ & 28 & & 54 & \\
\hline $\begin{array}{l}\text { Gump and Lepore } \\
\text { (1960) }\end{array}$ & $66^{1}$ & $>2$ & $22 \cdot 7$ & $\begin{array}{l}\text { Symptomatic re- } \\
\text { lapse with objec- } \\
\text { tive evidence of } \\
\text { recurrence }\end{array}$ \\
\hline $\begin{array}{l}\text { Colcock and } \\
\text { Vansant (1960) }\end{array}$ & 272 & $\gtrless 25$ & $\begin{array}{l}15 \cdot 2 \\
37 \cdot 1 \\
20 \cdot 6\end{array}$ & $\begin{array}{l}\text { Second resection } \\
\text { Total recurrence } \\
\text { Second resection }\end{array}$ \\
\hline $\begin{array}{l}\text { Barber, Waugh, } \\
\text { and Sauer (1963) }\end{array}$ & 88 & $>10$ & $26 \cdot 5$ & Second resection \\
\hline $\begin{array}{l}\text { Atwell, Duthie, } \\
\text { and Goligher } \\
\text { (1965) }\end{array}$ & $133^{1}$ & 0 to $>20$ & $\begin{array}{l}54 \cdot 9 \\
25 \cdot 6\end{array}$ & $\begin{array}{l}\text { Total recurrence } \\
\text { Second resection }\end{array}$ \\
\hline $\begin{array}{l}\text { Schofield (1965) } \\
\text { Present series }\end{array}$ & $\begin{array}{l}47^{1} \\
71^{1}\end{array}$ & $\begin{array}{r}>5 \\
1-10\end{array}$ & $\begin{array}{l}19 \cdot 1 \\
28 \\
17\end{array}$ & $\begin{array}{l}\text { Second resection } \\
\text { Total recurrence } \\
\text { Second resection }^{2}\end{array}$ \\
\hline
\end{tabular}

${ }^{1}$ Excluding post-operative deaths.

'Observed recurrence rates (for estimated rates at each year see text).

culated probabilities of a second resection in this series of 0.16 within five years and 0.26 within 10 years.

Medical treatment of regional ileitis frequently fails, perhaps because advanced structural changes in the ileum are usually present by the time treatment is begun. It seems possible that medical therapy designed to prevent recurrence after resection might give better results. The method of analysis described here might be used to compare the effect of different treatments given for this purpose.
SUMMARY

Three definitions of recurrence have been used to calculate by an actuarial method the recurrence rate after resection for chronic regional ileitis in a series of 78 patients from two hospitals. Recurrence of symptoms was likely in about half the patients, about one-quarter requiring a second resection, within 10 years of the first resection. The mortality rate from Crohn's disease was $12 \%$ within the same period.

In a small series of 15 patients the recurrence rate following a second resection was more than twice as great as after a first resection.

These definitions of recurrence and this mode of analysis are put forward as a possible basis for future analyses so that the results of treatment in different groups of patients may be compared.

We thank the staff of the two hospitals for allowing us to analyse and publish the results of their treatment and Mr. H. J. Bussey, B.Sc., for his help with the statistical analysis.

\section{REFERENCES}

Atwell, J. D., Duthie, H. L., and Goligher, J. C. (1965). The outcome of Crohn's disease. Brit. J. Surg., 52, 966-972.

Barber, K. W., Jr., Waugh, J. M., and Sauer, W. G. (1963). Surgical treatment of complication of regional enteritis. Arch. Surg. 86, 442-444.

Brown, C. H., and Daffner, J. E. (1958). Regional enteritis. II. Results of medical and surgical treatment in 100 patients. Ann. intern. Med., 49, 595-606.

Colcock, B. P., and Vansant, J. H. (1960). Surgical treatment of regional enteritis. New Engl. J. Med., 262, 435-439.

Crohn, B. B., and Yarnis, H. (1958). Regional Ileitis, 2nd ed., p. 139. Grune \& Stratton, New York and London.

Gump, F., and Lepore, M. J. (1960). Prognosis in acute and chronic regional enteritis. Gastroenterology, 39, 694-701.

Hill, A. B. (1966). Principles of Medical Statistics, 8th ed., pp. 232-236. The Lancet, London.

Pollock A. V. (1958). Crohn's disease. Brit. J. Surg., 46, 193-206.

Schofield, P. F. (1965). The natural history and treatment of Crohn's disease. Ann. roy. Coll. Surg. Engl., 36, 258-279.

Van Patter, W. N., Bargen, J. A., Dockerty, M. B., Feldman, W. H. Mayo, C. W., and Waugh, J. M. (1954). Regional enteritis. Gastroenterology, 26, 347-450. 